\title{
La paz hispanoportuguesa de 1715: la diplomacia ibérica en Utrecht
}

\author{
David MarTín Marcos* \\ Universidad Nacional de Educación a Distancia (UNED) \\ dmartinmarcos@geo.uned.es
}

Recibido: 29 de abril de 2010

Aceptado: 22 de junio de 2011

\section{RESUMEN}

La Paz de Utrecht es considerada por la historiografía un punto clave para la configuración de la Europa Moderna y el desarrollo de un nuevo sistema internacional basado en el equilibrio de poderes. Debido a esta circunstancia, la mayoría de las investigaciones acerca de estas negociaciones se han centrado en las relaciones entre Inglaterra, gran vencedora de la contienda, y las potencias borbónicas. En cambio, este trabajo tiene por objeto profundizar en la paz hispanoportuguesa de 1715 para contribuir a la construcción de una mirada plural sobre Utrecht. Asimismo, con el análisis de las conversaciones de paz entre Madrid y Lisboa, se pretende incidir en las numerosas desavenencias que seguían vigentes entre España y Portugal, después de la secesión de este último reino en 1668 y que conocieron un resurgir a comienzos del siglo XVIII.

Palabras clave: Guerra de Sucesión española, Paz de Utrecht, España, Portugal, Diplomacia.

\section{The Spanish-Portuguese Peace of 1715: the Iberian Diplomacy at Utrecht}

\begin{abstract}
Historians have considered the Peace of Utrecht as a key point for the configuration of Early Modern Europe and the development of a new international system based on a balance of powers. Given this, most part of researches about the negotiations have focused on the relations between England, the main war's winner, and the Bourbons. However, the aim of this article is studying the Spanish-Portuguese Peace of 1715 in depth and contributing towards a plural look to Utrecht. Furthermore, through the analyses of the Peace conversations between Madrid and Lisbon, this paper wants to highlight the disagreements between Spain and Portugal in force after the secession of 1668 and the revival experimented by them.
\end{abstract}

Key words: War of the Spanish Succession, Peace of Utrecht, Spain, Portugal, Diplomacy.

* "Programa Juan de la Cierva. Referencia JCI-2010-06893”. 


\section{EL ESTILO ANTECEDENTE}

Las negociaciones que en Utrecht pusieron fin a la Guerra de Sucesión española establecieron, frente a las pretensiones de los viejos poderes de Europa, un nuevo statu quo internacional basado en el equilibro terrestre ${ }^{1}$. A partir de ese momento, Inglaterra se confirmó como primera potencia y garante del nuevo orden, en detrimento de la Francia de Luis XIV. España, desprovista de sus posesiones en Italia y los Países Bajos, quedó relegada a un segundo plano. Por eso, es habitual que la historiografía española al referirse a este episodio diplomático dirija su mirada a la paz que se firmó con Inglaterra, la gran vencedora, y que, entre otros aspectos, sancionó que Menorca y Gibraltar pasasen a ser controlados por Londres². La plaza del Estrecho sigue hoy bajo soberanía británica y es probable que esa circunstancia motive aún más que sean las negociaciones hispanoinglesas las que, de entre las varias que se entablaron en Utrecht, más atraigan a los historiadores españoles. Sin duda, no faltan razones para ocuparse del tratado estipulado por el marqués de Monteleón y el duque de Osuna, de un lado, y el conde de Stratford y el obispo de Bristol, de otro, el 13 de julio de 1713: su firma, además de sancionar el ocaso español en Europa, hizo de Inglaterra un forzoso socio del gobierno de Madrid en la aventura del comercio americano; y marcó tan profundamente las relaciones entre ambos países que, aún hoy -casi tres siglos después- el Peñón sigue siendo un punto especialmente controvertido en sus agendas políticas. Sin embargo, la automática equiparación de Utrecht a ese aspecto y al irredentismo que dio pie al inmediato revisionismo mediterráneo que guió la política de los Borbones durante la primera mitad del siglo XVIII, ha provocado un excesivo descuido de los otros tratados que España firmó en ese congreso. Particularmente poco se ha dicho del que suscribió con Portugal en 1715.

La historiografía lusa, por su parte, ha dedicado mayor atención a esta paz. La ha considerado fundamental, junto con el acuerdo alcanzado con Francia también en Utrecht, en la consolidación del dominio y la expansión de Portugal en el interior de Brasil ${ }^{3}$. Si el acuerdo con los plenipotenciarios franceses supuso el control absoluto de las bocas del Amazonas y la exclusiva en la navegación de sus aguas, de las conversaciones con los españoles, los portugueses obtuvieron, en el Río de la Plata, la Colonia de Sacramento y lo que los franceses habían perdido en el otro gran río sudamericano: el derecho a asentarse en las tierras al norte de su cauce. No obstante, el sentido que la historiografía portuguesa ha concedido al tratado hispanoluso no ha ido mucho más allá. Y quizás sea lógico si se atiende a la historia de un país

Anderson, M. S.: "Eighteenth-Century Theories of the Balance of Power", en Hatton, R. y Anderson, M. S. (eds.): Studies in Diplomatic History: essays in Memory of David Bayne Horn, Londres, Longmans, 1970, pp. 183-198.

2 Véase la reciente síntesis de Albareda Salvadó, J.: La Guerra de Sucesión en España (17001714), Barcelona, Crítica, 2010, pp. 314-344.

3 El mejor ejemplo sigue siendo el clásico trabajo de Eduardo Brazão sobre el Congreso de Utrecht en el que se describen con detalle varios particulares de la paz hispanoportuguesa. BrazÃo.: Portugal no Congresso de Utrecht. 1712-1715, Lisboa, Imprensa Lucas, 1933. 
de pequeñas dimensiones, que contaba poco en las mesas de negociación de la Europa de la época y que, debido a su condición, había optado por una estrategia de expansión ultramarina que aparentemente anteponía la defensa de sus posesiones en América, África y Asia, a cualquier otra necesidad política. Sin embargo, lo cierto es que esa visión no era compartida en su totalidad por la diplomacia portuguesa de comienzos del XVIII, que también vio en la paz con España la constatación de que el país vecino reconocía por fin su estatus. "Sobretudo estimamos o Tratado porque se praticou nelle exactamente a igualdade entre a Coroa de Vossa Magestade e a de Castelha, emendandose agora o estilo antecedente", escribiría el conde de Tarouca, el principal responsable portugués en la negociación, poco después de que se concluyese el acuerdo ${ }^{4}$.

El estilo antecedente al que aludía el plenipotenciario, el de la superioridad del gobierno de Madrid frente a los Braganza, había estado presente en las relaciones entre Portugal y España más o menos de forma encubierta desde el reconocimiento de la restauración de la Monarquía lusa en 1668. De hecho, desde esa fecha ni siquiera en Portugal existía un consenso absoluto a cerca de quién era el verdadero soberano del reino. Como apuntaba el francés Torcy tras su breve embajada en el país en 1684, todavía eran muchos los fidalgos partidarios de "retourner sous la domination d'Espagne", con la esperanza de lograr los mejores cargos en un nuevo gobierno. ${ }^{5}$ El miedo a una hipotética insurrección con la connivencia de Madrid parecía, pues, estar más que justificado, y es que los movimientos de los españoles tampoco daban a entender que la corte de Carlos II hubiese desistido de sus pretensiones portuguesas.

Aunque en 1668 el gobierno de la reina Mariana había decidido extinguir el Consejo luso y suprimir las armas de Portugal en sellos y documentos para evitar provocaciones innecesarias, la llegada del conde de Humanes a la embajada de Lisboa, en 1672, había supuesto la vuelta a una política agresiva contra los antiguos rebeldes $^{6}$. El nuevo embajador había visto en la división entre quienes habían apoyado el asalto al poder del regente don Pedro, poco después de la paz hispanoportuguesa, y quienes defendían la legitimidad del depuesto Alfonso VI, una oportunidad excepcional para restablecer ante los portugueses la opción española como una vía que asegurase la paz en el reino. Observando el descontento de los opositores del regente, no había tardado en posicionarse a favor de los alfonsistas. Sin embargo, su estrategia no había tenido éxito. Tan sólo un año más tarde, se había visto envuelto en una conspiración que le había desacreditado ante el gobierno y había

${ }^{4}$ Copia de carta del conde de Tarouca a Juan V. Utrecht, 12 de febrero de 1715. Academia das Ciências de Lisboa [ACL], Serie Azul, 83, ff. 1r-2v.

5 Serrão, J. V.: Uma relaçao do reino de Portugal em 1684, Coimbra, Coimbra Editora Limitada, 1960, p. 19.

6 Valladares, R.: La Rebelión de Portugal 1640-1680. Guerra, conflicto y poderes en la Monarquía hispánica, Valladolid, Junta de Castilla y León, 1998, pp. 262 y 271-286. El problema de los emblemas portugueses no desaparecería y sería objeto de debate nuevamente en 1683 cuando se acuñasen monedas en Segovia con el escudo de Portugal, aparentemente "por omissión o ignoranzia de los oficiales" de la ceca. Carta de Francisco Enríquez Dávalos a Carlos II. Lisboa, 23 de noviembre de 1683. Archivo General de Simancas [AGS], Estado [E], leg. 7060, s. f. 
acabado con sus planes. No es que él, como habían querido hacer creer en Lisboa para ocultar el malestar que el régimen había despertado en el país, hubiese estado en el origen de la trama, pero su interés por incentivar la desafección había sido innegable. Con el desmantelamiento de la conjura se habían cerrado las puertas a un regreso de Alfonso VI y, veladamente, la posibilidad de que pudiese comenzar una paulatina reintegración de Portugal en la Monarquía de España se extinguía. Sin embargo, en realidad ése sólo era un ejemplo concreto de una corriente que se extendía a ambos lados de la frontera y que era partidaria de restaurar la unidad rota en 1640, ya fuera bajo una dinastía de signo español o portugués.

El regente, coronado en 1683 como Pedro II de Portugal, jamás se sustrajo a esa sensación durante el tiempo que ocupó el poder. Cuando la falta de descendencia de Carlos II se hizo más notable, trató incluso de utilizar el unionismo y el deseo de los españoles de evitar la fragmentación de la Monarquía en su propio beneficio. Tímidamente, a partir de 1697, circularon por Europa algunas informaciones procedentes de Lisboa que hablaban de los derechos del monarca sobre la herencia del Habsburgo y, aunque en un segundo plano, su nombre se coló entre los que se barajaban para ocupar el trono de España. En el fondo, no era ésta una mala salida para Madrid, donde pronto aparecieron pasquines -rápidamente traducidos al portugués- que elogiaban esta opción por considerar a Pedro II español, al ser portugués, y celebrar que, además, por sus venas corriese sangre castellana ${ }^{7}$. Pero sus posibilidades, por más que quisiese mostrarse próximo a sus vecinos e incluso se expresase en español con soltura ${ }^{8}$, eran remotas en medio de la vorágine en que se hallaba el continente. El Braganza no era ajeno a esa circunstancia y meses más tarde, invitado por Luis XIV a reconocer el último de los tratados de partición de La Haya, sólo señaló al respecto que, en el caso de que el emperador rechazase el acuerdo, los infantes de Portugal también podrían ser tenidos en cuenta para la sucesión española9. Lo importante era que haciéndose notar y aduciendo renunciar a sus derechos en la carrera por la herencia española, podía exigir ciertas compensaciones territoriales. Así, además de pedir a Luis XIV ser tratado como un igual tanto por él mismo como por Inglaterra y Holanda en el debate sucesorio, puso como condición para aceptar el tratado que se le entregasen Badajoz y Alcántara. El rey francés, ávido de sumar adeptos a su proyecto, no hizo objeciones a la propuesta portuguesa, por lo que Pedro II pudo concentrar entonces sus esfuerzos en obtener una respuesta semejante del gobierno inglés. Sin embargo, todas sus peticiones

7 Parecer que se fez em Castella por hum Titullo grande de hespanha sobre pretencer a successão de seus Reynos a El Rey de Portugal D. Pedro $2^{\circ}$ por falta de Successão de El Rey D. Carlos Segundo de Castilla [Copia]. [Biblioteca de Ajuda] BDA, 51-II-33, ff. 122r-155v.

8 "He speaks Spanish very well; and uses that Language as often as he is adress'd to in it by Foreigners." se dice del monarca en [CоLвAтсH, J.] An account of the Court of Portugal under the Reign of the present King Dom Pedro II with some discurses on the Interests of Portugal, with Regard other Sovereigns; containing a Relation of the most Considerable Transactions that have passed of late between that Court, and those of Rome, Spain, France, Vienna, England, \&c., Londres, Thomas Bennet, 1700.

9 Peres, D.: A diplomacia portuguesa e a Sucessão de Espanha, Barcelos, Portucalense, 1931, pp. 19-20. 
fueron infructuosas pues la corte de Londres se mostró tajante en su negativa. No sólo no estaba dispuesta a ceder ni un ápice en cuestiones territoriales, sino que justificaba su rechazo porque entendía que conceder voz a Pedro II en el reparto podría sentar un precedente en las reivindicaciones de futuros signatarios ${ }^{10}$.

Aunque apartado de la mesa de los grandes, la noticia de que Madrid se decantaba finalmente por el duque de Anjou permitió a Pedro II sobreponerse al golpe. Resultaba evidente que el viejo tratado de partición que había impulsado Francia quedaría huérfano y que Luis XIV no dudaría en aceptar el testamento de Carlos II, y era esa nueva situación para la que su gobierno tenía que estar preparado. A pesar de que, en principio, la subida de un Borbón al trono de España era lo peor que le podía pasar a Portugal, que perdía así un aliado frente al poderoso vecino, la corte de Lisboa comprendió que era mejor mostrarse amable y receptivo ante las propuestas que, en adelante, pudiesen llegar de París para evitar males mayores. Además, si Luis XIV volvía a necesitar -como había sucedido con el reparto- del concurso del mayor número posible de estados europeos para aislar al Imperio y acallar sus posibles protestas, Pedro II podía airear las pretensiones que había mostrado medio año atrás.

No sin debates entre los cortesanos y la abierta oposición del embajador austriaco Waldstein, el monarca acabó por firmar el 18 de junio de 1701 un tratado defensivo y ofensivo con Felipe V, quien había confiado su negociación a Pierre Rouillé, el embajador de Luis XIV en Lisboa. ${ }^{11}$ Reconocía, así, al joven Borbón en el trono de Madrid y se comprometía a cerrar sus puertos a aquellas naciones que declarasen la guerra a España por ese motivo; a cambio, Madrid (o mejor léase París) se comprometía a enviar a Portugal suficientes tropas y navíos para defender el país y sus posesiones, si la alianza y sus disposiciones desembocaban en ataques contra el patrimonio territorial del Braganza. En el plano militar era, en consecuencia, un acuerdo más o menos equitativo; pero eran los puntos referentes a posesiones y aspectos económicos los que inclinaban netamente la balanza a favor de Lisboa. Si para hacer efectivo el acuerdo, Luis XIV había tenido que abandonar antes algunas de las reivindicaciones que Francia venía haciendo en el Marañón, el punto número 14 del tratado establecía la cesión de la Colonia de Sacramento y abolía el tratado provisional de 1681. Mientras que los artículos 2 y 7, respectivamente, instituían que España indemnizase a Portugal por las pérdidas que hasta la fecha había sufrido en el asiento de negros en las Indias y se comprometiese a pagar junto con Francia, dos terceras partes la manutención de Catalina de Braganza -viuda de Carlos II de Inglaterra-, en caso de que Guillermo III, con motivo de la guerra, la interrumpiese.

El tratado, sin embargo, no duró demasiado. Ya fuera por el buen hacer de John Methuen, el representante inglés en Lisboa ${ }^{12}$, o por la desatención que los borbónicos

10 Szarka, A. S.: Portugal, France, and the coming of the War of the Spanish Succession, 16971703 (tesis doctoral), Columbus, Ohio State University, 1976, p. 194.

11 Tratado de mutua alianza entre España y Portugal firmado el 18 de junio de 1701, en CANTILlo, A. del: Tratados, convenios y declaraciones de paz que han hecho con las potencias extranjeras los monarcas españoles de la Casa de Borbón desde el año de 1700 hasta el día, Madrid, Alegría y Charlain, 1843, pp. 28-32.

12 Véase Francis, D. H.: "John Methuen and the Anglo-Portuguese Treaties", The Historical Review, III (1960), pp. 102-124. 
demostraron para con Portugal, Pedro II optó por sustituir el trato preferencial que había dispensado a las Dos Coronas por una fría neutralidad en el verano de 1702. El frente aliado estaba ganando fuerza y si, como había señalado el embajador portugués en París, Francia necesitaba de "todo o seu poder para defender os [puertos] de Nápoles, Sicilia e de todas as Indias", y los territorios portugueses serían "os mais espostos" a un ataque ${ }^{13}$, quizás era el momento de que Lisboa rectificase la línea de su política exterior y retomase la vía atlántica ${ }^{14}$. En los meses siguientes, se sucedieron los debates sobre la posición que debía mantener Lisboa, mas en la balanza se hacía sentir, por encima de todo, una máxima que favorecía enormemente a los austracistas y que Pedro II había observado desde su llegada al poder: el peligro que suponía para los Braganza el buen entendimiento de París y Madrid. Como decía Luis da Cunha en sus memorias, "o sistema que por tantos anhos durou entre as duas Coroas de França e Hespanha, e fazia a tranqüilidade de Portugal, e que finalmente hera chegado o tempo sem poder esperar outro de arriscar alguma couza para se alargarem os Confins de tam estreitos dominios" 15 .

En ese sentido, el tratado que Pedro II suscribió con el Imperio, Inglaterra y Holanda el 16 de mayo de 1703 y por el que se decantaba por el bando aliado y se comprometía a reconocer al archiduque Carlos como legítimo monarca de España, resultaba particularmente beneficioso para los intereses portugueses ${ }^{16}$. Según una cláusula secreta del acuerdo, una vez que el Habsburgo fuese coronado como Rey Católico, las plazas de Badajoz, Alburquerque, Valencia y Alcántara, en Extremadura; y La Guardia, Tuy, Bayona y Vigo, en Galicia; amén de los territorios al norte del Río de la Plata, pasarían a estar bajo el dominio de Lisboa. Nuevamente, la posibilidad de desplazar la frontera con España hacia el este y el norte estaba detrás de los movimientos del Braganza, que, sin embargo, a diferencia de lo que había sucedido en las ocasiones anteriores, esta vez se descubría ante su vecino. Ciertamente el apoyo económico y militar de Austria y las Potencias Marítimas invitaba a ello, aunque no menos importante resultaba para generar un notable optimismo la convicción de que, según sostenían los coligados, el pueblo se levantaría contra Felipe V en cuanto entrasen sus tropas en España. No es que se imaginase en la corte de Lisboa que la guerra sería un camino de rosas, pues en ningún momento se sostuvo que con la ayuda popular los contingentes militares aliados fuesen innecesarios ${ }^{17}$, pero se acertaba a prever que ese factor podría ser decisivo para el

13 Copia de carta de José da Cunha Brochado a Pedro II. París, 5 de febrero de 1702. BDA, 49$\mathrm{X}-39$, ff. $5 \mathrm{r}-8 \mathrm{v}$.

${ }_{14}$ Freire Costa, L., Da Restauração a Methuen: ruptura e continuidade, en CARDOSO, J. L., et Alii, O Tratado de Methuen (1703): Diplomacia, Guerra, Politica e Economia, Lisboa, Livros Horizonte 2003, pp. 31-49.

${ }_{15}$ Memorias de D. Luis da Cunha, ministro do Senhor Rey Don João o Quinto na Corte de Londres, Paris e Holanda [desde la Paz de los Pirineos a la muerte de Pedro II], ACL, Serie Azul, ms. 302, pp. 258-259.

16 Borges de CAStro, J.: Collecção dos tratados, convenções, contratos e actos publicos celebrados entre a Coroa de Portugal e as mais potencias desde 1640 até ao presente, I, Lisboa, Imprensa Nacional, 1856, pp. 140-187.

${ }_{17}$ Memorias de D. Luis da Cunha..., cit., p. 261. 
resultado final de la contienda. De ahí que, antes de que se iniciasen las hostilidades contra Felipe V, Pedro II publicase en Lisboa un manifiesto escrito en castellano y dirigido a españoles "de cualquiera grado, estado y condición", en el que justificaba su decisión de apoyar al archiduque y romper los acuerdos con los Borbones ${ }^{18}$. En él, se denunciaba el incumplimiento por parte de Luis XIV de varios puntos estipulados con Lisboa, pero, además, se incidía en la difícil situación que había supuesto para España la llegada del duque de Anjou y en que "todo lo útil y lo honorífico" hubiese quedado en manos de los franceses. Ante ese panorama - se sentenciaba en el documento- Pedro II estaba dispuesto a "quitar los grillos que la ambición francesa había puesto a la Nación Española"; si Dios había puesto "en sus manos una parte de las Españas, qual es la Lusitania", él pretendía la libertad de todo "el nombre Español".

La referencia a lo español como marco en el que se encuadraba Portugal no era nueva en el vocabulario de Pedro II, que ya había blandido esa arma en el debate sucesorio. Pero ahora hacer ver a los habitantes del país vecino que él, un rey español, procuraba expulsar al extranjero era una forma panfletaria de argumentar su propia invasión y, de paso, colaborar con los austracistas en el debate identitario que les enfrentaba a los borbónicos. Sin embargo, encontraría una réplica contundente no mucho después.

En Mogiganga de mogigangas, papelón de papelones ${ }^{19}$, un impreso publicado por un felipista anónimo probablemente a finales de 1704, se presentaba a Pedro II como un monarca ridículo y al reino que gobernaba, como una tierra de traidores incapaces de mantenerse leales a causa alguna. En él, se hacía un repaso a los controvertidos episodios de 1640 y 1668 y se terminaba por referir que si en la primera fecha los portugueses habían abandonado a Felipe IV y en la segunda el rey había apartado del trono de Lisboa a su hermano, el entonces soberano, no de muy buenas maneras, nada positivo podía esperarse de la monarquía lusa. Como ha señalado Pedro Cardim, todo ello contribuía a fomentar la imagen de un reino marcado por la tendencia a la traición y como tal, se cuestionaba una dinastía, la de los Braganza, que se había hecho con la Corona de forma dudosa ${ }^{20}$. De nuevo, la legitimidad del gobierno portugués era cuestionada y aunque no parecía que en ese momento ese fuese una argumento que importase en España, en Lisboa sí que surgirían voces favorables aún a una alianza con los Borbones. Correrían nuevos rumores que conjeturarían exageradamente acerca de la posibilidad de que a su

18 Justificação de Portugal na resolução de ajudar à ínclita nação espanhola a sacudir o jugo francez, e a collocar no real throno da sua monarchia El-Rei Catholico D. Carlos III; Publicada em Lisboa a 9 de março de 1704, en Borges de CASTro, J., op. cit. (nota 15), pp. 198-207.

19 Anónimo, Mogiganga de mogigangas, papelón de papelones, manifiesto de manifiestos, idea de ideas, reflexión de reflexiones, cuento de cuentos, miscelánea de todo surtimiento, fiesta de capa y espada, tramoyas y cascabel gordo, sueño fantástico, histórico, prognóstico, y jurídico, en que se representa lo que fue, es y será con distinción de lo que es, y lo que no es - Impresso em Lisboa a costa de Don Pedro que es quien lo ha de pagar todo. n. 1, [170?].

20 CARdim, P.: "Portugal en la guerra por la sucesión de la Monarquía española", en GARcíA GonzÁlez, F. J. (coord.): La Guerra de Sucesión y la batalla de Almansa. Europa en la encrucijada, Madrid, Sílex, 2009, p. 224. 
llegada, el archiduque Carlos se proclamase rey de Portugal, y no de Castilla, y apartase al Braganza de su trono ${ }^{21}$.

Como era de esperar, el arribo de Carlos al puerto de Lisboa no produjo ningún problema para la soberanía de Pedro II, que recibió a su aliado con grandes honores $^{22}$ y encargó para la ocasión un conjunto pictórico de fuerte contenido simbólico. Según una nota anónima conservada en el Archivo Secreto Vaticano, en las paredes de una de las galerías que tuvo que atravesar el archiduque colgaban cuadros con escenas del Antiguo y el Nuevo Testamento con leyendas que hacían referencia a algunos de los protagonistas del conflicto sucesorio ${ }^{23}$. En la serie, además de evocarse la figura de Felipe V apartada de España, con el lema "per te mossa est tempestas", una pintura sobre la transfiguración de Jesús en el Monte Tabor simbolizaba la coronación del Habsburgo como rey de España; mientras que las representaciones de la muerte bajo las aguas del Mar Rojo del faraón que persiguió a Moisés en su huída de Egipto o de Judas ahorcado tras vender a Jesucristo, eran, respectivamente, alusiones a Luis XIV ahogado "nel sangue francese" y al cardenal Portocarrero, a quien se acusaba de haber traicionado la causa imperial. Se trataba, por tanto, de un programa decorativo que presentaba la visión oficial que desde Lisboa se hacía del conflicto, pero lo que en él se evocaba resultaría muy difícil de materializar en la guerra.

Los Aliados no encontraron en Castilla ni las facilidades ni el cálido recibimiento de la población que había pronosticado el almirante Juan Tomás Enríquez de Cabrera tras abandonar las filas borbónicas en $1702^{24}$. Al contrario, el recelo de los grupos populares se hizo patente desde un principio y alcanzó cotas insostenibles cuando el ejército comandado por el marqués de las Minas entró en Madrid a finales de mayo de 1706. Bien porque el comportamiento de las tropas en ningún momento permitió ganarse la confianza de las comunidades locales o bien porque los intereses de ingleses y holandeses se situaban ya claramente en la costa y no en el interior de la península, la empresa no produjo ningún rédito para Lisboa, que impotente tuvo que observar cómo el ejército, presionado por una contraofensiva borbónica, abandonaba la capital semanas más tarde ${ }^{25}$. Por eso, si algo podía deducirse de la irregular campaña era que no parecía que en adelante las Potencias Marítimas fuesen a apoyar a Portugal en pos de posibles reivindicaciones territoriales ni que les importase especialmente su insistencia por demostrar que

21 Ibidem, p. 225.

22 Detalles de la llegada del archiduque en: Carta do Conde da Ericeira D. Francisco Xavier de Menezes para o Vice Rey da Jndia Caetano de Mello de Castro, ACL, Serie Azul, ms. 383, ff. 186-198.

23 Nota de' Quadri preparati dalla Maestà del Rè di Portogallo per ornamento della Galleria in cui doveva passeggiare il Rè Carlo Terzo di Spagna, n. 1., 25 de diciembre de 1703. ASV, Fondo Bolognetti, 137, ff. 118-119.

24 Cunha de Ataíde, T. da: Memórias históricas (introducción de vasconcelos de Saldanha, A. y Radulet, C. M.), Lisboa, Chaves, Ferreira, 1990, p. 146.

25 Cluny, I.: "Estrategias políticas de la Monarquía portuguesa frente a la Guerra de Sucesión española”, en Álvarez-Ossorio, A., García García, B. J. y León Sanz, V.: La pérdida de Europa. La guerra de Sucesión por la Monarquía de España, Madrid, Fundación Carlos de Amberes-SECC, 2007, pp. 663-664. 
la España austracista reconocía abiertamente "o muyto que devia a sua liberdade ao valor Portuguez" 26 .

El impago parcial del capital con el que los ingleses se habían comprometido a sufragar la manutención del ejército portugués así lo dejaba entrever ya en el mes de agosto ${ }^{27}$. Si bien, la confirmación definitiva del creciente desapego se produjo tras la muerte de Pedro II -el 9 de diciembre de 1706- y la subida al trono de su hijo Juan V. A comienzos de 1707 el nuevo monarca era un inexperto muchacho de 17 años y los Aliados no tardaron en intentar sacar partido de su bisoñez presionándole para obtener un nuevo tratado que redujese los subsidios que hasta el momento disfrutaba Portugal. Sin embargo, aunque buscaron convencerle alegando que el escenario bélico ya no se situaba en el occidente peninsular, el monarca rechazó la propuesta ${ }^{28}$. Al fin y al cabo, la aportación que su gobierno hacía, en términos humanos, a las tropas que guerreaban en España no era despreciable, como se desprendería del alto número de bajas lusas que se registraría en el mes de abril en la batalla de Almansa ${ }^{29}$.

Pero pese a las dificultades militares, las primeras medidas del joven Braganza no fueron encaminadas a paliar esa situación. Se concentraron en ensalzar su condición regia ante Europa, una obsesión que había marcado a los soberanos portugueses desde 1640 y les había conducido a tejer una densa red diplomática en el continente que legitimase su poder. Con la intención de dar continuidad a esa política, Juan V hizo de las estrategias matrimoniales una de sus principales preocupaciones. Su casamiento, en 1708, con la archiduquesa María Ana de Austria, que ya había sido objeto de negociación cuando aún era un infante, consolidaba las relaciones de Portugal con el Imperio y le aproximaba aún más a la causa austracista en España. A los ojos del archiduque, el monarca luso se había convertido en uno de sus principales apoyos y, por eso, no sólo exigiría ante los aliados ese mismo año que se respetasen los proyectos del portugués, sino que en 1711, iniciada la aproximación entre franceses e ingleses para poner punto final a la guerra, escribiría a la corte, ya como emperador, proponiendo una estrecha colaboración con el objeto de asegurar una "ventajosa paz" en las inminentes negociaciones ${ }^{30}$. No en vano, ésa debía de ser ahora la máxima

${ }^{26}$ Quarta Relaçam dos successos das armaz portuguezas, progressos de El Rey Catholico Dom Carlos III e dos mais aliados desta Coroa, Imprenta de Antonio Pedrozo Galram, Lisboa, 19 de agosto de 1706.

27 Rellação do que está devendo a nação ingleza por conta das mezadas annuais e da campanha de fim de Agosto corrente, e dos mantimentos que receberão de Janeiro do anno prezente de 706 conforme os ajustamentos, que se tem feito athe prezente abatido, o que tem entregue por conta de húa e outra obrigação [por Luis Monteiro Gaspar Salgado]. Lisboa, 6 de agosto de 1706. ACL, Serie Azul, ms. 281, f. 132.

28 Francis, D.: The First Peninsular War. 1702-1713, Londres, Ernest Benn, 1975, p. 237.

29 Un testimonio directo es aportado por el capellán portugués Domingos de Conceição quien señala que de las 18.000 unidades entre caballería e infantería que componían el ejército aliado, sólo quedaron unos 3.000 infantes, y que se perdieron 800 caballos. ConcEIÇÃo, D.: Diario bellico da entrada do nosso exercito na Hespanha no tempo da Grande Alliança contra Felippe $5^{\circ}$. ACL, Serie Vermelha, ms. 45, ff. 37v-39r.

30 León SAnz, V.: "Una Habsburgo en el Portugal de los Braganza. El matrimonio de Juan V con la archiduquesa María Ana de Austria”, en Martínez Millán, J. y Marçal Lourenço, M. P.: Las relaciones discretas entre las monarquías hispana y portuguesa: las Casas de las Reinas (siglos XV-XIX), vol. I, Madrid, Polifemo, 2008, p. 414. 
preocupación del gobierno portugués, que en los últimos envites de la contienda se afanaría en mantener su posición y no descolgarse de los movimientos de Holanda e Inglaterra. Aunque el matrimonio le había servido para mejorar la imagen del Reino, Felipe V seguía ocupando el trono de Madrid y era con los Borbones con quien habría de negociar ${ }^{31}$.

\section{NEGOCIAR ANTES DE LA NEGOCIACIÓN}

Las primeras conversaciones en tierras holandesas pusieron de manifiesto que Inglaterra habría de ser la primera nación en despachar sus asuntos para a partir de ahí ejercer de árbitro de la negociación. La guerra había servido para confirmar su potencial bélico y se hallaba en grado de imponer sus preferencias. Ésa era la situación ante el arranque de las reuniones y nada alteraría el guión por más que el conde de Tarouca considerase en privado que esa actitud iba "contra o Tratado de Alliança de Portugal". En su opinión, sólo quedaba aguardar y observar los movimientos de los holandeses a pesar de que le pudiese "custar grande dificultade pois ao mesmo tempo que não me declaro, necesito de falar com todos" 32 .

Es difícil precisar hasta qué punto Tarouca tenía razón. Pero lo cierto es que ante esa cuestión Madrid se hallaba más próxima a Londres que Lisboa. Para los borbónicos resultaba más sencillo presionar a un Portugal aislado que no apoyado por Inglaterra. Por eso, no deja de sorprender que en la primavera de 1711 se descubriesen unas negociaciones secretas entre el gobierno luso y un agente borbónico para alcanzar una tregua en la frontera y una paz separada. Este fallido acuerdo, que había puesto en comunicación al borbónico marqués de Bay con Corte Real, motivó hondas críticas de los representantes de las potencias coligadas en Lisboa contra las que las excusas del gobierno - argumentando que se trataba de una estratagema de los enemigos para desestabilizar la alianza- no tuvieron ningún efecto ${ }^{33}$. Sólo la certeza de que Juan V no había estado al corriente de las conversaciones hasta que fueron destapadas por Lord Portmore, el embajador de la reina Ana ante el monarca, evitó que la crisis se agravase ${ }^{34}$. A fin de cuentas, desvelada la trama, Portugal podía verse obligado a lanzar una ofensiva contra España para lavar su

31 La muerte de José I y la marcha del archiduque rumbo a Fráncfort, donde sería coronado emperador, había provocado en Lisboa una gran preocupación: "se devia temer que Phelippe acabasse de reduzir Catalunha, e voltasse todas as suas forças contra Portugal; quanto mais, que a vista das disposiçoens da Corte de Gram Bretanha, era mui provável que sobindo Carlos ao Trono Imperial conservaria Phelippe o de Espanha, de que seguiria ficar Portugal com hum vezinho offendido, que difficultosamente converia em cederlhe as Praças, que havia estipulado com o seu competidor". Anónimo, Memórias: depóis da liga de 1703 até a paz de Utreque. ACL, Serie Azul, ms. 124, s. f.

32 Carta del conde de Tarouca a Juan V. n. 1, 2 de octubre de 1711. ACL, Serie Azul, ms. 79, ff. 80r-88r.

33 Carta de Diogo de Mendonça a Luis da Cunha. Lisboa, 11 de mayo de 1711. ACL, Serie Vermelha, ms. 2, ff. 49r-53r.

34 Carta de Lord Portmore a Lord Dartmouth. Lisboa, 17 de mayo de 1711. The National Archives [TNA], State Papers [SP] 89/21, ff. 187-188. 
mala imagen, y ésa era una opción que convenía a la Alianza tras los fracasos de Brihuega y Zaragoza ${ }^{35}$.

Tras un episodio que había tenido como principal escenario La Raya afloraba la divergencia de intereses entre Portugal e Inglaterra. Mientras Londres abogaba por nuevas campañas contra los borbónicos, Lisboa quería limitar el uso de sus tropas a la defensa de sus territorios. Seguían vigentes sus viejas reivindicaciones sobre la frontera y en adelante los representantes del gobierno luso expondrían con mayor claridad su deseo de incluir sus exigencias en los puntos a negociar con los borbónicos. Para Juan V resultaba fundamental que cuestiones como la barrera se mantuviesen vigentes en la agenda de las conversaciones y hacia tal fin dirigiría sus maniobras. Como se exponía en un despacho a Luis da Cunha, no sería justo que incluyendo prerrogativas de príncipes que no habían firmado el tratado de 1703, "se haja de omitir a nossa tão solemnemente prometida nos artigos 22 e $23^{\prime \prime 36}$.

Sin embargo, el acuerdo que había sancionado el nacimiento de la alianza antiborbónica quedaba demasiado lejos. Los preliminares de Londres de 1709 -la última base legal sobre la que debían asentarse las negociaciones de Utrecht- contenían referencias a la "barrera holandesa" pero no a la que demandaban los portugueses ${ }^{37}$. Así las cosas, el horizonte se dibujaba poco claro para los representantes portugueses. Aunque exigían la inclusión de ese punto en las conversaciones que en primer término se tendrían con Francia, acabarían comprendiendo que su ascendiente era demasiado débil para obtener "seguranças" de los Aliados sobre este particular" Sin apoyos en las conversaciones que se abrieron el 29 de enero de 1712, Tarouca decidiría no hacer mención al punto de la barrera ni al de la Colonia de Sacramento, la otra vieja reivindicación de Portugal frente a los españoles. Sería paradójico, se justificaba ante Lisboa, presentar las reivindicaciones territoriales en el congreso aduciendo el peligro que suponía para Portugal que la Monarquía hispánica estuviese en manos del Borbón, cuando los miembros de la Alianza aún no habían reconocido a Felipe V como Rey Católico ${ }^{39}$. En principio no le faltaba razón. Si se daba por hecho que el nieto de Luis XIV permanecería en el trono de España, sería difícil arrancar el compromiso de París en otros temas que, de esta forma, podían presentarse como hipotéticas compensaciones frente a las ventajas que se concederían a los Borbones.

Pero en el fondo, como reconocería el propio Tarouca no mucho tiempo después, el hecho de que aún no se supiese quién era el rey de España no dejaba de ser un

35 Carta de Anthony Corbiere a Erasmus Lewis. Lisboa, 13 de mayo de 1711. Ivi, ff. 144-145.

36 Ídem. Lisboa, 13 de noviembre de 1711. ff. 88r-91r.

37 BRAZÃo, E., op. cit. (nota 3), pp. 40-41. También Eduardo Brazão señala que Tarouca ya había recibido instrucciones para defender las plazas de la frontera hispanoportuguesa en los encuentros que previamente habían tenido lugar en La Haya, sin que se concluyese en ellos nada claro. BRAZão, E.: $A$ diplomacia portuguesa nos séculos XVII e XVIII, II, Lisboa, Resistência, 1980, pp. 23-27.

38 Carta del conde de Tarouca a Diogo de Mendonça. n. 1., 5 de enero de 1712. ACL, Serie Azul, ms. 80, ff $1 \mathrm{r}-5 \mathrm{v}$.

39 "Pela mesma razão não falei ainda em que se restituisse a nova Colonia do Sacramento. [...] Sómente me expliquei sobre as terras do Cabo do Norte, por ser a única pertenção que temos directamente com França, sem depender de quem houver de Dominar em Espanha". Ídem. Utrecht, 8 de marzo de 1712. ff. $57 \mathrm{r}-67 \mathrm{v}$. 
contratiempo para Portugal ${ }^{40}$. Coronado el archiduque como emperador Carlos VI y reducido el territorio austracista a la zona nororiental de la península Ibérica y la isla de Mallorca, la continuidad de Felipe $\mathrm{V}$ en el trono de Madrid era prácticamente incuestionable. Negociar sin tener en cuenta su condición regia se había convertido en un ejercicio que no conducía a ninguna parte. Además, a esas alturas el gobierno portugués, a título individual, no sólo era incapaz de hacer que la Corona se tambalease en la sien del Borbón sino que era uno de los principales interesados en que el que había sido su enemigo se convirtiese ahora en un interlocutor válido en las negociaciones. Ésa era la posibilidad a la que se asía para que sus reivindicaciones territoriales a ambos lados del Atlántico pudiesen salir adelante, si bien aún faltaba que el resto de los coligados trabajasen en la misma dirección. Aunque Tarouca aseguraba que el único punto en que los Aliados parecían ponerse de acuerdo era en no solicitar la "restituição de Espanha", los holandeses todavía mantenían vigente su deseo de "pedilla" como una fórmula que evitase que el Imperio entrase a examinar asuntos que le enfrentaban a La Haya" ${ }^{41}$. En tales circunstancias resultaba prácticamente imposible iniciar cualquier tipo de negociación con España y la corte lisboeta se vería obligada a arriesgar en sus movimientos. En las órdenes que se enviarían a Tarouca en el mes de julio se expondría la posibilidad de que, incluso sin el concurso de Inglaterra, el representante portugués dejase entrever que su gobierno estaría dispuesto a proseguir la guerra contra Francia y España ${ }^{42}$. Sin embargo, por más que el conde y Luis da Cunha (que se había unido a las negociaciones en abril de 171243) también defendiesen que no debía firmarse un armisticio con los Borbones sin que Londres se comprometiese a incluir "la barrera" en las negociaciones ${ }^{44}$, Lisboa no se encontraba en grado de poder condicionar a los ingleses ni de alterar el ánimo de sus enemigos sin el concurso de los Aliados. Los españoles, que hasta el momento habían observado con cierta indiferencia los envites de Portugal, no variarían su postura con respecto a Juan V.

Únicamente el paso del tiempo y el avance de las negociaciones entre Madrid y Londres permitirían que españoles y franceses aceptasen firmar un armisticio con Lisboa el 7 de noviembre. Sólo era un alto el fuego, pero el gobierno portugués evitaba al menos quedarse aislado en las negociaciones -poco antes las Provincias Unidas ya se habían mostrado partidarias de iniciar las conversaciones-. Para su rúbrica había sido necesario la mediación del obispo de Bristol, uno de los plenipotenciarios ingleses en Utrecht, y que los enviados de Juan V accediesen a referirse a Felipe V como Rey de España, y no como Rey de Castilla, pues "El Rei Felipe possuhia mais reinos que o de Castella", pero al margen de esa precisión, no habría mayores inconvenien-

40 Ídem. Utrecht, 31 de mayo de 1712. ff. 182r-190v.

${ }^{41}$ Ídem. Utrecht, 31 de mayo de 1712. ff. 155r-161v.

42 Carta de Diogo de Mendonça al conde de Tarouca. Lisboa, 15 de Julio de 1712. ACL, Serie Vermelha, ms. 3, ff. 11r-13v.

43 Luis da Cunha había llegado a Holanda procedente de Londres, donde había desempeñado el cargo de embajador extraordinario desde 1697. Véase Cluny, I., D. Luís da Cunha e a ideia de diplomacia em Portugal, Lisboa, Livros Horizonte, 1999, pp. 57-64.

44 BrazÃo, E., op. cit. (nota 3), p. 73. 
tes por parte de los españoles ${ }^{45}$. Las bases para la futura negociación y los intereses de Madrid iban en otra dirección. Fundamentalmente había que tratar que Inglaterra no hiciese suyas las pretensiones lusas; de otro modo, Portugal se convertiría en un asunto escabroso e incómodo para el Borbón.

Por eso en las instrucciones que a finales de diciembre se enviaron desde Madrid al duque de Osuna -elegido junto con el marqués de Monteleón para representar a Felipe V en Utrecht- se decía que había que ofrecer alternativas a la reina Ana I de Estuardo capaces de "desvanecer las controbersias" erigidas por Portugal ${ }^{46}$. Aunque los ingleses eran partidarios de que Madrid no entregase a Lisboa ninguna de las plazas de la frontera hispanoportuguesas, sí que veían con buenos ojos la cesión de la Colonia de Sacramento ${ }^{47}$. Se trataba a fin de cuentas de una especie de compensación, pero el gobierno borbónico no estaba dispuesto a aceptar el trueque. Sacramento -se informaba a Osuna- estaba en la zona influencia española decretada por el Tratado de Tordesillas de 1494 y aunque después de la fundación de la colonia en 1680 y su destrucción por los españoles un año después, se había alcanzado un acuerdo ( 7 de mayo de 1681) por el que los portugueses podían vivir en la región siempre y cuando no hiciesen nuevas construcciones o reparasen las antiguos, jamás había llegado a ratificarse. Muerto Carlos II, Felipe V había aceptado en 1701 ceder a los portugueses el territorio en el marco del acuerdo por el que Pedro II reconocía al Borbón en el trono de España, pero rota la alianza - continuaba la instrucción- se había procedido a expulsar a los portugueses de aquel terreno. Si bien, el monarca estaba dispuesto a retomar el acuerdo de 1681. Ésa era su última oferta.

Por otro lado, frente a las acusaciones portuguesas contra la supuesta dilación y falta de compromiso de los españoles en la negociación, el documento era fuertemente contrario. En él se refería que en verdad eran los lusos quienes no ofrecían garantías para que diesen comienzo las conversaciones y que su actitud redundaba en el retraso. Aún no se sabía si estarían dispuestos a aceptar un territorio equivalente a Sacramento o si, a cambio de incluir en las negociaciones el asiento de negros, aceptarían estudiar la situación de los bienes que algunos súbditos de Felipe $\mathrm{V}$ poseían en Portugal y de los tres navíos españoles apresados por los portugueses antes del comienzo de la guerra. Pero en realidad las demoras sólo favorecían a los españoles. Aunque Juan V deseaba que Londres alcanzase la paz con París y Madrid, temía el aislamiento y pedía desde Lisboa a Tarouca que hiciese todo lo posible para que tanto las conversaciones que estaban a punto de concluirse con Francia como las que se

${ }^{45}$ Carta del conde de Tarouca a Diogo de Mendonça. Utrecht, 25 de octubre de 1712. ACL, Serie Azul, ms. 80, ff. 325v-371r. En realidad el uso del término "Castilla" y no "España" resulta habitual en la documentación portuguesa relativa a la Edad Moderna, al equiparar en muchas ocasiones a España con toda la península Ibérica, en cuyo seno tenía lugar la contraposición Portugal-Castilla como fórmula identitaria desarrollada por Lisboa.

46 Instrucción para desvanezer las controversias movidas sobre la conclusión de la Paz, se adjunta a carta de Felipe V al duque de Osuna. Buen Retiro, 28 de diciembre de 1712. AGS, E, leg. 6173, s. f.

47 "...to render their demands more easy they had orders to tell us, that excepting their interests In Brasile they could depart from all the rest". Carta del conde de Stratford y John Robinson a Henry Saint John. Utrecht, 3 de enero de 1713. TNA, SP, 89/246, ff. 1-4. 
iban a iniciar con España no se rompiesen ${ }^{48}$. Era el 8 de abril de 1713 y sólo 3 días más tarde los Aliados, con la excepción del Imperio, firmarían la paz con Francia. Portugal obtendría de Luis XIV importantes concesiones en el Amazonas, pero no conseguiría arrancarle ningún compromiso con respecto a España ${ }^{49}$.

En el mes de julio, cuando llegó la hora de los acuerdos de la Monarquía de Felipe $\mathrm{V}$ con los coligados, Juan V no pudo evitar quedarse descolgado. Lo que entonces se decidió - entre otros asuntos, la cesión de Gibraltar a Londres- iba a influir sobremanera en el discurrir de las negociaciones que habían iniciado portugueses y españoles en el mes de junio. Como refería Tarouca, era de esperar que los plenipotenciarios españoles, tras haber rubricado los tratados con Saboya e Inglaterra, apostasen por avanzar en el proceso negociador sin siquiera entrar a discutir los puntos que aún no hubiesen sido aprobados por la corte de Lisboa o incluso abandonasen Utrecht $\sin$ alcanzar un acuerdo ${ }^{50}$. Es decir, iba a resultar muy complicado que el gobierno luso tuviese tiempo de dotarse de un nuevo aparato jurídico para hacer frente a la Monarquía hispana, como también iba a ser difícil obtener nuevas cesiones territoriales en la península Ibérica después de que los españoles hubiesen perdido el control del Estrecho.

Según un despacho enviado al duque de Osuna en el mes de mayo, la voluntad de Felipe V en este sentido era clara: "las cosas deben ser restablecidas de una y otra parte sobre el pie en que se hallaban antes del principio de la Guerra y por consequencia restituidas de buena fee todas las Plazas, castillos y país tomado, y ocupado de una parte y otra durante el curso de la Guerra" ${ }^{51}$. Era un discurso que trataba de invalidar las conquistas portuguesas de la Puebla de Sanabria, Alcañices y otros núcleos fronterizos, pero que al mismo tiempo buscaba legitimar la actuación española al otro lado del Atlántico así como los intereses que el gobierno mantenía con respecto a otros puntos. Si los portugueses habían cancelado el acuerdo de 1701 por el que Felipe V les había entregado Sacramento, era lógico que no tuviesen "oy título alguno para pretender poseer este Fuerte y Colonia". Sin embargo, no eran los aspectos jurídicos los que más parecían importar para sustentar esta pretensión. Era de esperar, se decía con pragmatismo, que los ingleses apoyasen a la Monarquía "a causa de ser ellos también interesados por la idea en que están y principio que han establecido de que ninguna nación más que la Española à de gozar de este comercio [en el Río de la Plata]". Por último -concluía el despacho-, Osuna tenía que hacer todo lo posible para que en el nuevo tratado hispanoluso se incluyese una mención a las posesiones y rentas que algunos vasallos del Borbón tenían en Portugal, con objeto de que pudiesen ser restituidos sin tener la obligación de "vivir, quedar, ni residir" en ese país. El asunto de las restituciones de los bienes patrimoniales, sin resolver desde 1668, seguía vigente.

48 Carta de Diogo de Mendonça a conde de Tarouca. Lisboa, 8 de abril de 1713. ACL, Serie Azul, ms. 3, ff. 100r-100v.

49 Borges de CAStro, J.: op. cit. (nota 15), pp. 242-255.

50 Carta del conde de Tarouca a Diogo de Mendonça. Utrecht, 18 de julio de 1713. ACL, Serie Azul, ms. 81, ff. 134v-142v.

51 Despacho del marqués de Grimaldo al duque de Osuna. Madrid, 13 de mayo de 1713. AGS, E, leg. 6178 , s. f. 
Pocos días antes de la apertura oficial del congreso, Tarouca tendría ocasión de comprobar en primera persona el ánimo de los españoles. En una cena organizada por el conde de Stratford -uno de los mediadores ingleses en la paz hispanolusa- a la que también asistió el marqués de Monteleón, el plenipotenciario de Felipe V le haría entender que el gobierno portugués no debía

"esperar a minima Barreira, que nem El-Rey seu Amo, nem a Nasção o consentiría, nem havia instrumento para obrigalo; pois que os Inglezes, em quem nos outros nos confiavamos, pactarão logo ao principio expresamente com Phelipe $5^{\circ}$ que não daría a menor porção a Portugal no continente de Espanha, e que este consentimeno dos Inglezes fora o preço de tudo o que os Castelhanos lhe concederão a elles" ${ }^{\prime 52}$.

\section{LAS CONVERSACIONES DE PAZ}

La primera de las conferencias hispanolusas de Utrecht tuvo lugar el 10 de julio de 1713. A ella asistieron el marqués de Monteleón y el duque de Osuna, en nombre de Felipe V, y el conde de Tarouca y Luis da Cunha, de parte de Juan V. Celebrada en la residencia del obispo de Bristol, representante, junto con Stratford del gobierno de Londres en el congreso, la reunión tenía que servir como punto de partida para unas negociaciones en las que se dirimirían los temas que ya habían sido planteados por Tarouca y Monteleón en reuniones anteriores, al tiempo que colocaba a Inglaterra en una situación destacada en la mediación. Su posición podía inclinar la balanza de uno $\mathrm{u}$ otro lado, y tanto Lisboa como Madrid trataron de adaptarse a esa circunstancia con fórmulas idénticas mediante la presencia en Utrecht de da Cunha y Osuna, sus respectivos embajadores ante la reina Ana I de Estuardo. Estaban en juego las plazas de la frontera hispanoportuguesa, la Colonia de Sacramento, la deuda del asiento de negros, los barcos apresados en Buenos Aires y en el Algarve y las restituciones de los bienes que súbditos del Rey Católico tenían en Portugal ${ }^{53}$.

Ante una agenda repleta y engordada por ambas partes, las desavenencias surgieron en los primeros compases del encuentro. Los portugueses exigían la demolición de Badajoz o que al menos se convirtiese en una plaza compartida que les permitiese tener un mejor acceso a la villa de Olivenza, pero los españoles se negaron a hacer cualquier concesión. Aseguraban que no tener plazas para defenderse de Portugal era uno de los mayores perjuicios que se le podía hacer a la Monarquía y entendían que, hallándose la Corona exhausta y falta de fuerzas, no tenía sentido que se exigieran nuevas seguridades para demostrar su apuesta por la paz. Por esa misma razón, también se mostraron contrarios a ceder Alburquerque y la Puebla de Sanabria, a pesar de que los portugueses alegaron que tras su conquista habían destinado importantes inversiones para mejorar su defensa. Las cuestiones territoriales eran a priori asuntos

${ }^{52}$ Carta del conde de Tarouca a Diogo de Mendonça. Utrecht, 9 de junio de 1713. ACL, Serie Azul, ms. 81, ff. 83r-94r.

53 Carta del conde de Tarouca a Diogo de Mendonça. Utrecht, 22 de junio de 1713. ACL, Serie Azul, ms. 81, ff. 94r-115r. 
no negociables para los plenipotenciarios de Felipe $\mathrm{V}$, que tampoco fueron receptivos a la hora de tratar el futuro de Sacramento. La colonia -dijeron- se hallaba en tierras "españolas" según los tratados de Tordesillas (1494) y Zaragoza (1529) y el acuerdo por el que se había entregado a Portugal (1701) se había roto con la presente guerra. Ante ese panorama, el único punto que los lusos lograron sacar adelante fue el del asiento de negros, consiguiendo que desde Madrid se diesen nuevas órdenes para que se reactivasen los pagos que se habían visto interrumpidos durante la contienda sucesoria ${ }^{54}$.

Del lado español, las pretensiones sobre los navíos apresados y el asunto de las restituciones planteadas por Monteleón y Osuna corrieron suerte dispar. Aunque Tarouca accedió a negociar la situación de los barcos capturados en el Río de la Plata, se negó a tratar el segundo punto al considerar que la materia era "sertamente nova" y que por tanto ni él ni da Cunha estaban "instruidos". En realidad, no es que se tratase de un asunto desconocido - las quejas de las Casas de Aveiro y Linhares no habían cesado desde 1668-, pero mantener ciertas reservas para debatirlo era una forma de contrarrestar las negativas de los españoles ante las propuestas portuguesas. Era la misma estrategia empleada en el caso de Badajoz (ciudad que los españoles no iban a ceder y a cuyo control - entendía el conde- Portugal podría desistir siempre y cuando sirviese para avanzar en otros frentes) y el resultado no podía ser otro que un proceso lento plagado de controversias. Aunque con repetidas expresiones "do dezejo de reconsiliar a amizade entre os vasalhos das duas Coroas", aquella primera reunión era la constatación del desencuentro ${ }^{55}$.

A pesar de la magnitud de las desavenencias, la segunda sesión no se demoró en exceso. Tuvo lugar el día 26 de nuevo en la residencia del obispo de Bristol ante la presencia de Stratford y del propio prelado. En ella las tensiones fueron menores que en el encuentro inaugural y gracias en parte a los portugueses, que accedieron a incluir en el debate el pago de los navíos de Buenos Aires y el asunto de las restituciones, y a apartar provisionalmente la demolición de Badajoz y la situación de Puebla y Alburquerque de las negociaciones, se pudo garantizar la buena marcha de las conversaciones ${ }^{56}$. Ceder en asuntos que se antojaban de difícil término para Lisboa era una fórmula para alcanzar los más plausibles objetivos de Sacramento y el asiento de negros, y el razonamiento habría de demostrarse particularmente efectivo. Cuando se abordaron ambas cuestiones, los portugueses pudieron comprobar que los españoles apenas sí iban a contradecirles en adelante en lo relativo al asiento y que, aunque se negaban a abandonar las tierras entre Brasil y el Río de la Plata, estaban dispuestos a negociar el futuro de la disputada plaza por más que estuviese en sus manos. Eran buenos síntomas para Portugal pero el hecho de que, junto a esos puntos, las pretensiones españolas hubiesen pasado a engrosar la lista de temas a tratar en el congreso constituiría un serio contratiempo para Tarouca y da Cunha. Pese a que se empeñasen en considerar la toma de los navíos de Buenos Aires un episodio al margen de la

54 Ibidem.

55 Ibídem.

56 Carta del conde de Tarouca a Diogo de Mendonça. Utrecht, 8 de julio de 1713. ACL, Serie Azul, ms. 81, ff. $115 \mathrm{r}-134 \mathrm{v}$. 
guerra y en hacer ver que las restituciones a los caballeros castellanos con bienes en Portugal ni siquiera habían sido valoradas en el tratado de 1701, para Monteleón y Osuna éstos eran asuntos de primera magnitud.

Las instrucciones de la corte madrileña así lo dejaban entrever (vid. supra) pero curiosamente la importancia otorgada a ambas cuestiones habría de provocar notables desavenencias entre los plenipotenciarios de Felipe V. Sobre todo al ocuparse de los navíos apresados por los portugueses. Cuando Tarouca explicó que la captura de un barco en las costas del Algarve no estaba relacionada con la guerra sino con otros problemas y sugirió que la controversia se tratase en otro momento, los españoles no acertaron a dar una respuesta conjunta. Lejos de mostrar cohesión ante los presentes, Osuna reprochó a Monteleón cierta condescendencia con los portugueses y manifestó que en caso de tener que apartar ese punto, el resto del tratado debería cerrarse en Madrid, donde se hallaba Lord Lexington, que podría hacer las veces de mediador. Aunque Stratford intervino recordando que no era para eso para lo que les habían enviado sus soberanos a Utrecht y los españoles acabaron aceptando dejar pendiente el asunto de los navíos, la escasa sintonía entre Osuna y Monteleón había quedado al descubierto $^{57}$. Frente a la amistad que se profesaba la pareja de representantes portugueses $^{58}$, las desavenencias de los enviados del Borbón eran fruto de una rivalidad por alcanzar un mayor protagonismo individual en el congreso.

Manifestar públicamente los problemas internos de la delegación española no era quizás el medio más adecuado para conducirse en futuras sesiones pero lo cierto es que, según evidencia la correspondencia con Lisboa, los portugueses no dieron mayor importancia al incidente. En cambio, sí preocupaba a los enviados de Juan V la actitud de los mediadores. "Os Inglezes não somente nos não ajudão a adquirir algua couza, mas nos querem precisar a perder tanto cabedal", referirían a Lisboa al término del encuentro ${ }^{59}$. Si las buenas relaciones con Londres tenían que ser la mejor prueba de la opción atlántica que Portugal había elegido en 1703 y que habría de confirmar en los tratados de paz ${ }^{60}$, los diplomáticos portugueses no parecían confiar demasiado en sus aliados. Sus palabras denotaban recelos y no ocultaban el temor a que el arbitraje inglés acabase por perjudicar los intereses lusos.

Puede que por ello Monteleón acudiese a Stratford pocos días después para plantearle en privado las reivindicaciones españolas sobre las Casas de Aveiro y Linhares, y conocer su parecer. Pretendía el marqués reafirmar las aspiraciones de la Corona española, si bien su interlocutor se limitaría a recomendarle que escribiese a Londres para que la reina Ana pudiese pronunciarse al respecto y de inmediato comunicaría a Tarouca el contenido de la reunión. Sin embargo, a pesar del gesto del inglés para con el conde, éste vería en el encuentro un nuevo motivo de queja hacia Stratford e

\footnotetext{
57 Ibídem.

58 Cunha, L. da: Instruçoes políticas [1736] (edición de Dinız SiLva, A.), Lisboa, Comissão nacional para as comemorações dos descobrimentos portugueses, 2001, p. 50.

59 Carta del conde de Tarouca a Diogo de Mendonça. Utrecht, 8 de julio de 1713. cit.

60 Monteiro, N. G.: "Identificação da política setecentista. Notas sobre Portugal no início do período joanino", Análise Social, vol. XXXV, 157 (2001), p. 975.
} 
informaría de ello a la corte lisboeta ${ }^{61}$. El malestar que le provocaba la actuación de los ingleses se radicalizaba, pero al mismo tiempo estaba obligado a entenderse con ellos si quería que el acuerdo con los españoles fuese ventajoso para Juan V. En agosto, tras asimilar esa necesidad, él mismo pactaría con el obispo de Bristol y el conde de Stratford un proyecto de tratado, que se remitiría a sus respectivos gobiernos para que diesen el visto bueno y sirviese de guía para las negociaciones con los representantes borbónicos ${ }^{62}$.

Recibido el aprobado y con nuevas instrucciones del Braganza, el siguiente encuentro con los españoles se produjo el 15 de septiembre ${ }^{63}$. Habían transcurrido más de dos meses desde la última reunión y Tarouca fue directo en su interpelación a los enviados de Felipe V. Quería saber cuál era el parecer que habían recibido de Madrid sobre la negociación. Una vez más fue Osuna el más reacio a especificar su postura, expresándose "com pouca clareza", y Monteleón quien ofreció una respuesta más satisfactoria. Según el marqués, Felipe V estaba dispuesto a ceder "temporalmente" Sacramento después de que se ajustasen el resto de artículos o, en su defecto, "hum equivalente". Tarouca no contemplaba que la soberanía de la plaza no fuese absoluta pero a pesar de que hizo ver al español que de no ser así la paz sería "poco sólida", éste le explicó que su pretensión era justa ya que al haberse roto el pacto de 1701 era lógico que la situación del enclave volviese a ser la que gozaba en tiempos de Carlos II. Aunque ya no habría avances, Tarouca tendría la impresión de que los "castelhanos virião a ceder, porque como o Marquez de Monteleon explicava sempre a força dos nossos argumentos ao Duque, julgamos que era a fim de dispollo, e capacitalo na materia" ${ }^{\prime 4}$.

Aún quedaba por tratar el asunto de las restituciones de las Casas pero lógicamente ya no serían los portugueses quienes llevasen las riendas de la conversación. Ahora era el turno de que los españoles presionasen. Sin embargo, pese a la complacencia demostrada por Monteleón y Osuna en el punto anterior, los enviados de Felipe V no serían correspondidos por los plenipotenciarios de Juan V, que tacharían su pretensión de "tanto mais estranha". Según explicaba Tarouca, la Casa de Braganza siempre había respetado el artículo octavo de la Paz de 1668, que sancionaba -en su opinión- que los vasallos de la Monarquía lusa no pudiesen gozar de sus bienes cuando cambiasen de domicilio contra la voluntad de su príncipe, pero ir más allá era salirse del acuerdo. Ciertamente era una interpretación peculiar que no tenía en cuenta la consiguiente naturalización de los portugueses en los territorios españoles y Monteleón se ocupó de hacer ver al conde la "lógica" del acuerdo. Aunque el artículo octavo no hiciese mención expresa a que los portugueses que se quedasen en

${ }^{61}$ Carta del conde de Tarouca a Diogo de Mendonça Corte-Real. Utrecht, 18 de julio de 1713. ACL, Serie Azul, ms. 81, ff. 134v-142v.

62 Ídem. Utrecht, 13 de agosto de 1713. ff. $145 \mathrm{v}-156 \mathrm{v}$.

63 A pesar de que los plenipotenciarios españoles se encontraban en La Haya desde el último encuentro y que Tarouca tenía pensado trasladarse a esa ciudad para dar comienzo a la negociación cuanto antes, finalmente no fue necesario su traslado ya que los españoles optaron por regresar a Utrecht antes de que éste iniciase su viaje. Ídem. Utrecht, 22 de septiembre de 1713. ff. 156v-198v.

64 Ibídem. 
España podrían gozar de sus bienes en Portugal, implícitamente se debía entender así, pues era en ese contexto en el que había sido suscrito; y si en el momento no se había explicado con claridad, debía subsanarse el error con la firma del nuevo tratado. La posición española era firme y, pese a los intentos de Tarouca de desestabilizar a Monteleón exigiendo que en el caso contrario se restituyese el patrimonio del duque de Medina Sidonia, no habría cambios. Gaspar Alonso Pérez de Guzmán había sido para los españoles un traidor y no se contemplaba que tuviese ningún derecho en el país ${ }^{65}$. Ambas partes parecían por momentos radicalizarse y, así las cosas, tampoco habría acuerdo en lo relativo a los navíos apresados.

La entrada en barrena de las negociaciones quedó confirmada en una reunión organizada por los ingleses poco después con el objeto de presentar ante españoles y portugueses un documento que establecía un principio de acuerdo. A pesar de que en él se establecía que Sacramento pasase finalmente para Portugal y que el asunto de los barcos detenidos y la restitución de las Casas quedase en manos de árbitros fuera del congreso, Tarouca no sólo señalaría que ya se conocía su opinión sobre el primero y el segundo punto, sino que haría saber a los ingleses que la negociación no necesitaba ni de expediente ni de mediadores ${ }^{66}$.

Sus palabras eran una velada crítica al arbitraje que el viejo aliado de Portugal en la guerra había puesto en práctica en Utrecht después de cerrar sus tratados y reflejaban el sentir de su gobierno. Si Inglaterra hacía las veces de mediador, ¿no era lógico que favoreciese a Juan V en la medida de lo posible? Y sin embargo -se lamentaba el secretario de Estado, Diogo de Mendonça Corte Real, en Lisboa-, la reina Ana no sólo no se comprometía a garantizar una paz entre España y Portugal que incluyese los puntos que exigía el Braganza, sino que parecía obligar a los portugueses a desistir de sus pretensiones sobre la barrera, sin que los españoles abandonen las suyas. Ante esa situación, la cuestión no admitía dudas en lo referente a las Casas:

consentirião elles que os vassalos dessa Coroa, que fougisem para França ou Olanda e quizesem ficar naquelles estados, se lhes restituisem Duvre, Portmud...? pois logo como podem pertender que S. M convenha que ao Duque de Arcos por exemplo se lhe restitua Setubal, e Cezimbra, de que hé Alcayde Mor, e Aveiro de que hé Donatario ${ }^{67}$.

Las nuevas instrucciones que Corte Real remitió a Tarouca también fueron redactadas en términos semejantes. Sólo se aceptaría la ratificación del artículo octavo y antes que consentir las pretensiones de los españoles sobre los bienes patrimoniales, Juan V continuaría la guerra con el Borbón ${ }^{68}$. Al fin y al cabo, era conveniente aprovechar el desgaste que la campaña de Cataluña estaba produciendo en Felipe V. Si

${ }^{65}$ Ibídem. Sobre la conspiración andaluza de 1641 y sus vínculos con la rebelión de Portugal puede consultarse: Sala Almela, L.: Medina Sidonia: El poder de la aristocracia, 1580-1670, Madrid, Crítica, 2008 .

${ }_{66}$ Carta del conde de Tarouca a Diogo de Mendonça, cit. Utrecht, 22 de septiembre de 1713.

67 Carta de Diogo de Mendonça a José da Cunha Brochado. Lisboa, 3 de octubre de 1713. ACL, serie vermelha, ms. 3 , ff. $145 \mathrm{r}-146 \mathrm{r}$.

68 Carta de Diogo de Mendonça al conde de Tarouca. Lisboa, 17 de octubre de 1713. Ivi, ff. $145 \mathrm{r}-146 \mathrm{v}$. 
incluso en ese contexto el monarca mantenía su empeño en el tema de las Casas y se mostraba contrario a respetar los puntos del tratado de 1701, qué no haría -señalaría el propio Corte Real más adelante- cuando se hallase libre, y "em pacifica posse de Barcelona" ${ }^{69}$.

Pero en realidad Portugal no se hallaba en condiciones de mantener una guerra por su cuenta y ya no habría nuevos enfrentamientos con el país vecino. Ni lo recomendaban los nada desdeñables réditos que el gobierno lisboeta estaba obteniendo en las negociaciones de Utrecht, ni la actitud de los españoles parecía tan extrema como para recurrir a las armas. En un proyecto redactado por el francés Jean Orry a finales de octubre de 1713, y que habría de servir de guía para Osuna y Monteleón, se aceptaba sin grandes problemas la cesión de Sacramento y simplemente se aconsejaba que en el caso de "remitir al Juizio de algún Prínzipe amigo de las dos Partes" los puntos de las Casas, los navíos y el asiento de negros, se intentase que la restitución de la plaza fuese "conforme al Tratado Provisional". Si algo se daba por descontado en Madrid es que el enclave rioplatense iba a integrar las posesiones de la Monarquía portuguesa al término del congreso ${ }^{70}$. Por eso, cuando Tarouca planteó la amenaza de la guerra en un nuevo encuentro con los españoles, sus palabras estuvieron muy lejos de obtener el efecto esperado. Monteleón y Osuna se limitaron a recordar que Sacramento siempre podría ser sustituido por un equivalente ${ }^{71}$.

Por el momento eso era lo único que los españoles estaban dispuestos a discutir y las desavenencias que entonces surgieron, desembocaron en un nuevo estancamiento de las negociaciones. Sólo en marzo de 1714 se alcanzó un principio de acuerdo. El nuevo compromiso ratificaba la cesión de Sacramento, mantenía vigente el polémico artículo octavo en los términos en que se redactó en 1668 y establecía que la deuda del asiento de negros se pagase en líquido y que los gastos de los navíos se descontasen de la misma. Por delante sólo quedaba que fuese ratificado por Juan V y Felipe V y, según apuntaba Tarouca, incluso los españoles consideraban que "os artigos passarão em Madrid sem reparos" ${ }^{72}$. La paz parecía estar cada vez más cerca, pero lo cierto es que no sería tan sencillo. A pesar de las buenas perspectivas dibujadas por Tarouca y la confianza que el conde tenía en que Luis XIV presionase a su nieto para que firmase la $\mathrm{paz}^{73}$, la respuesta del gobierno español se demoraría irremediablemente y en Lisboa crecería la sensación de que la intención de los españoles "hé so de interternos e não concluir o tratado" 74 . A fin de cuentas, qué sentido tenía que Felipe V hubiese enviado a comienzos de 1714 al príncipe de Bournonville ${ }^{75}$ a Utrecht para

${ }^{69}$ Ídem. Lisboa, 19 de octubre de 1713. ff. 148v-149r.

70 Projecto executado por messieur Orry para las cartas que se escrivieran al Duque de Osuna y al marqués de Monteleón. Madrid, 30 de octubre de 1713. AGS, E, leg. 6174, s. f.

${ }_{71}$ Carta del conde de Tarouca a Diogo de Mendonça. Utrecht, 30 de noviembre de 1713. ACL, Serie Azul, ms. 81, ff. 234r-246v.

72 Ídem. Utrecht, 31 de marzo de 1714. ff. 296r-310r.

73 Ídem. Utrecht, 26 de abril de 1714. ff. 317v-321r.

74 Carta de Diogo de Mendonça al conde de Tarouca. Lisboa, 1 de junio de 1714. ACL, Serie Vermelha, ms. 3, ff. 167r-169r.

75 El príncipe Michel Joseph de Bournonville y barón de Caprès había sido el último castellano de la fortaleza española de Gante, hasta que tuvo que capitular y entregar la plaza en 1709. Tarouca señala que 
componer las desavenencias de Monteleón y Osuna, si cuando por fin ideaban un proyecto se retrasaba una y otra vez su firma. La única explicación que podía buscarse ante esa situación era precisamente ésa, la del entretenimiento, pero los españoles no tardarían en mostrar a los portugueses sus verdaderas intenciones.

El día 3 de junio el marqués de Bay envió desde Badajoz una carta dirigida a Corte Real en la que se recogía la voluntad de Felipe $\mathrm{V}$ de que la paz no fuese concluida en Utrecht sino "en estas fronteras". De esta forma, "nombrando de una y otra parte un Ministro" que pasase a tratar y conferir el ajustamiento, se acabaría con "la suma dilación" en que se encontraba envuelto el proceso, explicaba el general ${ }^{76}$. La proposición, sin embargo, no podía ser ahora más contraria a los intereses de Portugal y la respuesta del secretario de Estado fue negativa. Habiéndose gastado tanto tiempo en las conferencias de Utrecht y habiendo confiado en la mediación de Ana I de Inglaterra, significaba Corte Real, "não seria justo tornar a ventilarse ponto algum neste negocio" en lugar que no fuese aquél donde habían comenzado las negociaciones ${ }^{77}$. A pesar de que Tarouca había llegado a insinuar en cierta ocasión que para determinados aspectos Portugal no necesitaría el arbitraje de Londres (vid. supra), Corte Real tampoco dudó en comunicar a Henry Worsley, embajador inglés en Lisboa, el contenido del documento y asegurarle que Juan V no tenía intención de firmar la paz con España sin contar antes con Inglaterra ${ }^{78}$. Su apoyo era fundamental y por más que en Utrecht Monteleón tratase de mostrar a los impacientes plenipotenciarios portugueses que las demoras del gobierno borbónico podían deberse a que se "hubiese abierto otro camino por el qual las dos cortes pudieran en derechura entenderse y acordarse" 79 , Juan V sólo contemplaba continuar por la senda de la ciudad holandesa.

Ni siquiera la noticia del fallecimiento de Ana I en el mes de agosto le hizo cambiar de opinión. Y la posibilidad de que las conversaciones cambiasen de escenario se hizo más difícil cuando Stratford comunicó a Tarouca y a Monteleón que la nueva regencia le había ordenado obtener una respuesta clara sobre el estado en que se hallaban las negociaciones ${ }^{80}$. La paz iba a firmarse en Utrecht y si tanto españoles como portugueses querían tratar de modificar alguno de los puntos que desde hacía ya demasiado tiempo se discutían, lo poco que podían hacer era dirigir sus miras a quien

fue enviado a Utrecht para que aplacase las diferencias entre los dos plenipotenciarios españoles pero que lo único que logró fue "os fez separar a mais porque pondose da parte do Marquez de Monteleon, animou para dirigir pello seu arbitrio as dilligencias e negociaçoens, mais não bastou para reduzir a obstinada e maleciosa barbaridade com que o Duque de Ossuna antepossem a todas as considerações de dezejo de dilatar a concluzão dos negocios que trata". Carta del conde de Tarouca a Diogo de Mendonça, cit. Utrecht, 31 de marzo de 1714.

76 Carta del marqués de Bay a Diogo de Mendonça. Badajoz, 3 de junio de 1714. ACL, Serie Vermelha, ms. 3, ff. 170v-171r.

${ }_{77}$ Respuesta de Diogo de Mendonça al marqués de Bay. Lisboa, 7 de junio de 1714. Ivi, ff. $171 \mathrm{r}-172 \mathrm{r}$.

78 Carta de Diogo de Mendonça a Henry Worsley. Lisboa, 8 de junio de 1714. Ivi, ff. 172r-173r.

79 Carta del marqués de Monteleón al marqués de Grimaldo. Utrecht, 19 de julio de 1714. AGS, E, leg. 6176, s. f

80 Carta del conde de Tarouca a Diogo Mendonça. ACL, Serie Azul, ms. 81, ff. 364r-369r; y carta del marqués de Monteleón al marqués de Grimaldo. La Haya, 23 de agosto de 1714. AGS, E, leg. 6176, s. f. 
iba a ser el próximo rey de Gran Bretaña. La muerte de la última de los Estuardo situaba al elector de Hannover en el trono de Londres y que en su viaje desde su principado natal hasta su nuevo reino tuviese que atravesar las Provincias Unidas constituía una oportunidad perfecta para plantear ante la persona del soberano británico sus pretensiones sobre la paz.

Monteleón y Osuna tuvieron ocasión de ser recibidos por el futuro Jorge I la mañana del 20 de septiembre en La Haya. Sin embargo, la reunión hubo de demostrarse poco productiva. Las discrepancias entre los plenipotenciarios españoles se hallaban en ese momento en su punto álgido y durante el encuentro las intervenciones de ambos estuvieron plagadas de desacreditaciones mutuas y contradicciones acerca de la verdadera voluntad de Felipe $V$ en lo relativo al tratado. De esta forma, no sólo no fueron capaces de ofrecer al Hannover una postura clara con respecto al polémico artículo octavo de 1668, sino que invalidaron la posibilidad de conocer cuál era la opinión que el soberano tenía al respecto ${ }^{81}$.

La operación se saldaba con un fracaso, pero al menos habían sido capaces de conversar largo y tendido con el soberano y contrarrestar los contactos de los portugueses con él. Pocas horas antes de que Jorge de Hannover abandonase las Provincias Unidas rumbo a su nueva patria, Tarouca había podido declararle la "amizade e attenção, que le dedicaba Juan V, y comprobar que el nuevo rey estaba dispuesto a ofrecer "quantas seguranças podiamos dezejar de que havia de sustentar as promessas e empenhos da sua Coroa a nosso respeito" pero no mucho más que esas buenas palabras ${ }^{82}$. Quizás por eso en Lisboa comenzaba a cobrar fuerza la vieja idea de que el tratado se firmase en cualquier otro sitio antes que en Utrecht, donde la influencia inglesa en las negociaciones era tan notoria y estaba resultando poco productiva para sus intereses. Según pudo saber Henry Worsley, el embajador inglés en Portugal, a través de Diogo de Mendonça Cortereal, el representante de Juan V en París había mantenido una reunión con el marqués de Torcy en la que se había convenido la necesidad de cambiar el escenario de las negociaciones, mientras que el enviado de Luis XIV en la capital lusa había planteado una proposición similar para que fuese Lisboa el lugar donde se cerrase la paz ${ }^{83}$. Aunque Worsley rehusó ofrecer su parecer alegando que sólo tenía poderes para negociar un tratado comercial con Portugal, de inmediato advirtió a Londres de lo que estaba sucediendo en esa corte. Estaba asistiendo a un progresivo distanciamiento del aliado de Inglaterra en la guerra y las repercusiones de esta circunstancia eran cada vez más visibles en Holanda; allí Stratford lamentaba cómo la obstinación de los portugueses impedía el cierre del tratado ${ }^{84}$.

81 El duque de Osuna ofrece la mejor descripción de la audiencia. Carta del duque de Osuna al marqués de Grimaldo. Utrecht, 21 de septiembre de 1714. Ivi, s. f.; véase también Carta del marqués de Monteleón al marqués de Grimaldo. La Haya, 20 de septiembre de 1714. Ivi, s. f. Esta documentación desacredita la idea de que fueron los portugueses los únicos que se entrevistaron con el rey Jorge, como sostiene Isabel Cluny apoyándose en el testimonio indirecto de Tristão da Cunha de Ataíde. CLuNY, I., $O$ conde de Tarouca e a Diplomacia na Época Moderna, Lisboa, Livros Horizonte, 2006 , p. 312.

82 Carta del conde de Tarouca a Diogo de Mendonça. 27 de septiembre de 1714. ACL, Serie Azul, ms. 81, ff. 3 .

83 Carta de Henry Worsley a James Stanhope. Lisboa,7 de diciembre de 1714. TNA, SP, 89/23, ff. 104-107.

${ }_{84}$ Carta del conde de Stratford al vizconde de Townshead. La Haya, 11 de diciembre de 1714, Ivi, 84/250, ff. 272-275. 
Sus quejas denotaban hastío pero también preocupación. Ni siquiera sus advertencias a Tarouca de que con los retrasos su soberano pudiese obtener menos de lo que en ese momento se le ofrecía parecían funcionar, y lo peor era que, aunque no lo supiese, también a él se le estaba acabando el tiempo en la ciudad holandesa. Como ha señalado Lucien Bély, Utrecht significaba que la paz estaba a punto de hacerse sin que por ello tuviera que hacerse necesariamente en el mismo Utrecht ${ }^{85}$. Días después Stratford recibió una orden procedente de Londres que le dejó perplejo: debía poner punto final a su embajada en los Países Bajos y regresar a Inglaterra. Aunque el conde siguió los preceptivos pasos que debía recorrer en su retirada y tuvo su audiencia de despedida ante el gobierno de los Estados Generales el 31 de diciembre ${ }^{86}$, no pudo sino expresar su disconformidad al secretario de Estado de Jorge I. No entendía cómo después de una embajada tan larga como había sido la suya, se le ordenase terminarla sin previo aviso, justo cuando -entendía él- podía cerrar el capítulo de las negociaciones hispanoportuguesas, que, de otro modo, podrían alargarse aún más y perjudicar a Inglaterra. Por eso, aunque había cumplido con los deseos del monarca, también se había tomado la licencia de demorar unos días su marcha para conocer si Portugal, por fin, daría una respuesta favorable a la paz, tal y como preveían el duque de Osuna y el embajador de Francia ${ }^{87}$.

Stratford debía confiar plenamente en el Si portugués para arriesgarse tanto; el tiempo acabaría dándole la razón. El 6 de febrero, con el visto bueno de Juan V, Tarouca y da Cunha firmarían junto a Monteleón y Osuna la ansiada paz, echando por tierra la alternativa de negociar el tratado en Lisboa. La celeridad y la discreción en la toma de esta decisión habían marcado el obrar del gobierno portugués hasta tal punto que ni siquiera Worsley -representante, al fin y al cabo, de una parte implicada y beneficiada por la resolución- supo de ella hasta después. Aun así, su satisfacción desde la capital lusa era patente: "no good could have come from treating the Peace here", sentenciaría ${ }^{88}$. La paz se había firmado en Utrecht y, pese a las dilaciones, Inglaterra había anulado las pretensiones de Francia y había ejercido de mediadora. Además los puntos del tratado no ofrecían modificaciones sustanciales con respecto a los proyectos que anteriormente habían negociado españoles y portugueses, y ésa era una circunstancia que garantizaba aún más el equilibrio que Londres había planteado en el escenario posbélico. Se sancionaba en lo fundamental que Madrid mantenía sus plazas fronterizas mientras que Portugal recuperaba la Colonia de Sacramento y el pago atrasado de 296.000 escudos por el asiento de negros y anulaba las reivindicaciones sobre las $\mathrm{Casas}^{89}$. Para Felipe V las condiciones resultaban, por tanto, más que honrosas mientras que quizás para Juan $\mathrm{V}$ el botín podía presentarse un tanto exiguo

85 BéLY, L. : Espions et ambassadeurs au temps de Louis XIV, París, Fayard, 1990, p. 421.

86 Stratford, conde de: Harengue de Son excellence le Comte de Stratford, Ambassadeur Extraordinaire de la Grande-Bretagne auprès des Etats Genéraux, La Haya, 1714-1715? [impreso].

87 Carta del conde de Stratford al vizconde Townshead. La Haya, 1 de enero de 1715. TNA, SP, 89/250, ff. 291-294.

${ }_{88}$ Carta de Henry Worsley a James Stanhope. Lisboa, 9 de febrero de 1715. Ivi, 89/23, ff. 169-170.

89 Tratado de paz y amistad entre España y Portugal ajustado en Utrecht a 6 de febrero de 1715, en Cantillo, A., op. cit (nota 11)., pp. 164-1699. 
vistas las esperanzas depositadas en la contienda ${ }^{90}$. Sin embargo, como recordaba Tarouca, era útil y decoroso pues "não perdendo a Coroa de Vossa Magestade a minima porção dos seus dominios" y asegurando su presencia en el Río de la Plata, se había ganado sobre todo en el trato equitativo con España. Se había enmendado el estilo antecedente $^{91}$.

\section{UN BALANCE DE LA PAZ}

La recuperación de la normalidad en las relaciones entre las cortes de Madrid y Lisboa fue uno de los aspectos más celebrados por los portugueses, que consideraron esta circunstancia todo un éxito. Al menos, así lo quisieron presentar los enviados de Juan $\mathrm{V}$ al congreso de Utrecht, quienes se vanagloriaron de haber alcanzado una relación de igualdad con los españoles ${ }^{92}$. Ciertamente era éste un hito importante que ponía fin a los años de desencuentros en torno a los símbolos de la Corona portuguesa que habían seguido a la paz de 1668, pero no parece que esa normalización se debiese al buen hacer de Tarouca y da Cunha. Más bien, el establecimiento de unas relaciones de igual a igual entre las dos cortes respondió a un proceso más amplio, como era la participación de ambos países en unas negociaciones que incluían a las principales potencias del continente europeo. El mero hecho de que Portugal estuviese presente en ellas, por más que viese relegados sus acuerdos con los Borbones más tiempo de lo esperado, es suficiente motivo para pensar que se había puesto fin a la referida desigualdad con respecto a España. Lisboa había formado parte de la Alianza contra Luis XIV y su nieto en condiciones similares a las del resto de sus integrantes y no parece razonable creer que al comenzar las negociaciones alguien pusiese en duda al gobierno portugués. Ni siquiera sus enemigos. Por eso, la actitud de Tarouca y da Cunha al final del congreso, incidiendo en ese asunto, debe ser entendida como una fórmula con la que ocultar que el resultado de las negociaciones hispanolusas no había sido para Portugal tan bueno como se podía esperar.

En efecto, el rédito obtenido por Lisboa ante Madrid fue escaso. El empeño puesto en la creación de una barrera en la frontera con España que asegurase la defensa del país frente a posibles ataques del vecino mayor, uno de los principales objetivos militares de los Braganza, había acabado en fracaso -reconocido años más tarde por el propio da Cunha ${ }^{93}$ - y los portugueses no habían obtenido en el acuerdo ningún territorio que no poseyesen antes del estallido de la guerra. La colonia de Sacramento, que se mantendría bajo dominio portugués, ya había gozado del reconocimiento borbóni-

90 Leal de Faria, A., Arquitectos da Paz. A Diplomacia portuguesa da 1640 a 1815, Lisboa, Tribuna, 2008, pp. 137-138.

91 Copia de carta del conde de Tarouca a Juan $V$. Utrecht, 12 de febrero de 1715. cit.

92 Cluny, I.: op. cit. (nota 79), p. 318.

93 Para da Cunha Utrecht supuso una oportunidad perdida para construir la barrera en la frontera con España que garantizase la independencia del país en la península Ibérica. Años más tarde, como medio con el que garantizar la soberanía, sugeriría incluso el traslado de la corte lusa a Brasil. CunHA, L. da: Instruçoes políticas (edición de Diniz SiLva, A.), op cit., p. 60 y passim. 
co antes de que la guerra rompiese las relaciones de París y Madrid con Lisboa y que no se alterase su estatus había sido una manera de sancionar la vuelta a la normalidad en el trato entre las cortes en conflicto. En contraposición, las cláusulas aceptadas por los españoles no habían resultado particularmente indecorosas para Felipe V. Inglaterra, negociando la paz con Madrid antes que Portugal, había acaparado el cupo de cesiones territoriales y Gibraltar y Menorca se habían erigido en tremendos obstáculos para las pretensiones de los portugueses. Es ahí donde radica el motivo por el cual la frontera entre España y Portugal no se modificase al término del conflicto, aunque también, como en el caso del fin del estilo antecedente, se puede apelar a una causa mayor. A nivel europeo, los Aliados habían sido los grandes vencedores de la contienda, al acabar con las posesiones españolas en Italia y los Países Bajos, mientras que en España habían sido los Borbones quienes habían resultado victoriosos al mantener a Felipe $\mathrm{V}$ en el trono de Madrid. Portugal había jugado sus cartas en la península Ibérica y consecuentemente sus posibilidades de obtener rendimientos notables de su participación en la contienda habían quedado minadas enormemente.

El Tratado de 1715 confirmaba, en fin, que España, lejos de haber supuesto una amenaza para Portugal, se había tenido que defender de las incursiones aliadas desde tierras lusas y que, en las negociaciones con los enviados de Juan V en Utrecht, los representantes de Felipe V se habían dedicado a limitar los daños que las gravosas condiciones impuestas por Inglaterra iban a causar a la Monarquía. El acuerdo dejaba más o menos todo como antes de la guerra pero, en cualquier caso, se abría por fin un tiempo de paz entre las dos monarquías. 